\title{
TAKTYLIZM W FILMOWEJ TWÓRCZOŚCI JANA ŠVANKMAJERA
}

\author{
DOBROCHNA DABERT ${ }^{1}$ \\ (Uniwersytet im. Adama Mickiewicza w Poznaniu)
}

Słowa kluczowe: Europa Środkowa, film animowany, czeska animacja filmowa,
Jan Švankmajer, taktylizm, surrealizm

Key words: Central Europe, animation film, Czech Animation Movie, Jan Švankmajer, tactilism, surrealism

\begin{abstract}
Abstrakt: Dobrochna Dabert. TAKTYLIZM W FILMOWEJ TWÓRCZOŚCI JANA ŠVANKMAJERA. „PORÓWNANIA” 17, 2015. T. XVII. S. 151-163. ISSN 1773-165X. Problematyka tekstu ogniskuje się wokół taktylności jako idei twórczej obecnej w sztuce animacji filmowej Jana Švankmajera. Swoje rozumienie koncepcji taktylizmu Švankmajer wykłada w licznych tekstach teoretycznych, które $\mathrm{w}$ niniejszym artykule zostały zanalizowane i skonfrontowane $\mathrm{z}$ jego praktyką artystyczną. Za pomocą zmysłu dotyku, zdaniem praskiego artysty, można docierać do podświadomych, niepoznanych lub zapomnianych przeżyć, emocji, wrażeń, wspomnień, można zaktywizować wyobraźnię w niedostępny dla pozostałych zmysłów sposób. Poszukując możliwości przeniesienia w sferę sztuki animacji filmowej doświadczenia dotykowego, szczególną wagę Artysta przywiązuje do środków wyrazowych filmu, w tym makrodetalu w ruchu.
\end{abstract}

\begin{abstract}
Dobrochna Dabert. TACTILISM IN THE CINEMATOGRAPHIC WORK OF ŠVANKMAJER. "PORÓWNANIA" 17, 2015. Vol. XVII. S. 151-163. ISSN 1773-165X. The article focuses on tactilism as the artistic idea in the art of Jan Švankmajer's animation films The idea of tactilism as presented by Švankmajer in numerous theoretical papers is analysed and confronted with his artistic practice. According to the Prague-based artist, by means of the sense of touch one can reach the subconscious, unrecognised or forgotten experiences, impressions, memories and activate the imagination in a way that is inaccessible to other senses. In the search for the possibility to transfer the sense of touch into the art of film animation, the artist pays particular attention to means of artistic expressions including macro details in motion.
\end{abstract}

\footnotetext{
${ }^{1}$ Correspondence Address: dobro@amu.edu.pl
} 
Zdaniem Petera Hymesa, brytyjskiego historyka kina, znawcy Czechosłowackiej Nowej Fali, znaczące miejsce filmu animowanego w Europie Środkowej wynika ze specyficznych uwarunkowań politycznych w okresie powojennym, kiedy to:

Wschodnioeuropejskie przywiązanie do animacji było w dużej mierze efektem ubocznym nacjonalizacji i polityki kulturalnej - chodzi o stałe zatrudnienie i niskie płace, połączone z oddaniem tradycji ludowej i realizacją filmów dla dzieci. Lecz poza tym animacja była również ostoją sprzeciwu wobec panującej władzy. Podczas gdy w latach pięćdziesiątych stalinowska ortodoksja sprawowała pieczę nad filmami pełnometrażowymi, animacja chwilami cieszyła się niespotykaną wolnością. W tym okresie w Czechosłowacji reżyserzy tacy jak Jiř́ Trnka i Karel Zeman nakręcili swoje najlepsze filmy, które stanowiły liczącą się alternatywę dla disnejowskiego modelu. Wizualny eksperyment przetrwał $\mathrm{w}$ dopuszczalnych ramach, podczas gdy dzieła awangardowe i surrealistyczne były zakazane (Hymes 264-265).

Opinię P. Hymesa podziela także Paweł Sitkiewicz (Sitkiewicz 2015)2. Podobną prawidłowość odnotować możemy w polskiej kinematografii, w ramach której od połowy lat pięćdziesiątych rozwija się różnorodne formalnie i treściowo kino animacji za sprawą takich indywidualności twórczych jak: Jan Lenica, Walerian Borowczyk, Witold Giersz, Daniel Szczechura. W latach pięćdziesiątych i sześćdziesiątych tworzyli oni dzieła autorskie nastawione na poszukiwanie nowych technik i rozwiązań formalnych, służących przekazywaniu nierzadko poważnych treści społecznych, egzystencjalno- filozoficznych ${ }^{3}$.

Jan Švankmajer, debiutujący w czechosłowackim kinie animowanym w połowie lat sześćdziesiątych, jeden z najoryginalniejszych surrealistycznych twórców środkowoeuropejskich, tworzy posługując się animacją przedmiotową. Jego filmy krótko- i długometrażowe obudowane są traktatami teoretycznymi i komentarzami, w których twórca objaśnia swoją koncepcję animacji. W swoistym automanifeście zatytułowanym Desatero (Dziesięć przykazań) z 1999 roku zdefiniował rozumienie animacji, wyraźnie podkreślając, iż nie polega ona na wprawianiu w ruch przedmiotów, ale na ich ożywaniu, zgodnie z praktykami alchemicznymi. Nadanie życia obiektom służy ujawnieniu ich wewnętrznego życia i ukrytych treści,

${ }^{2}$ P. Sitkiewicz w rozdziale Czechostowacki film lalkowy zamieszczonym w pracy zbiorowej Kino epoki nowofalowej. Red. Tadeusz Lubelski, Iwona Sowińska, Rafał Syska. Kraków: Universitas, 2015, pisze: „Dziedzina ta zapewniała artystom umiarkowaną swobodę wypowiedzi, życzliwe zainteresowanie instytucji promujących kulturę narodową, pozwalała na stylistyczne eksperymenty, zwłaszcza $\mathrm{w}$ czasach walki $\mathrm{z}$ tzw. formalizmem, utrudniała natomiast kontrolę cenzurze, stając się $\mathrm{w}$ oczach zachodniej widowni wizytówka rzekomej swobody wypowiedzi artystów »zza żelaznej kurtyny«". S. 785.

3 Twórczy rozwój kina animowanego jako dzieła sztuki znajduje w Polsce kontynuatorów dotychczasowych dokonań choćby: Mirosława Kijowicza, Kazimierza Urbańskiego, Ryszarda Czekały, Juliana Józefa Antonisza, Krzysztofa Raynocha, Jerzego Kucię, Zbigniewa Rybczyńskiego, Daniela Szczechury, Piotra Dumały, Tomasza Bagińskiego, itd. 
skumulowanych za sprawą ludzi, którzy je dotykali przekazując im własne emocje. Stare przedmioty są rezerwuarem pamięci doznań oraz stanów emocjonalnych. Filmowanie jest jedynie formą ich uaktywnienia (Švankmajer 2001: 113-114).

Zdaniem Marcina Giżyckiego Jan Švankmajer czuje się:

duchowym prawnukiem magów, kabalistów, alchemików i artystów, którzy niegdyś zaludniali praski dwór cesarza (Rudolfa II - przyp. D.D.). Animacja z natury swojej ma wiele z alchemii, zajmuje się bowiem przemianą "stanu skupienia” materii, ożywia nieożywione. Ale u Švankmajera, jak u kogo innego, materia przechodzi ciągłe metamorfozy, transmutacje (Giżycki 229).

Natomiast Jakub Majmurek wprost dokonuje analogii z praktykami alchemicznymi, jakie ponoć dokonywały się kilkaset lat wcześniej na praskim dworze Rudolfa II. Podobnie postępuje Jan Švankmajer:

Gromadzi stare, zużyte, wyrzucone na śmietnik lalki, kukiełki, marionetki, niepotrzebne nikomu przedmioty i napełnia je życiem, niczym rabin Jehuda Löw swojego Golema. I tak jak Golem, światy Švankmajera są pokraczne i niezgrabne. „Życie” wychodzące spod rąk animatora jest jakby już od urodzenia zepsute, poronione, drugiej kategorii. Ale Švankmajer nie przestaje go tworzyć, bo właśnie w jego pokraczności szuka drzwi do prawdziwego wyzwolenia - wyobraźni, twórczej siły, pragnienia (Majmurek 2012).

\section{Švankmajerowski surrealizm}

Jan Švankmajer z czeskim ruchem surrealistycznym zetknął się już na początku lat pięćdziesiątych studiując na Wydziale Sztuk Stosowanych Wyższej Szkoły Artystyczno-Przemysłowej w Pradze. Zainteresował się wówczas praskim okultyzmem i alchemią spod znaku Rudolfa II i jego nadwornego malarza Giuseppe Arcimbolda, co stało się jednym z najistotniejszych inspiracji jego twórczości, ale także myślenia surrealistycznego. W jego przekonaniu, sztuce należy przywrócić czystość, jaką miała w czasach jej bliskich związków z magią, gdy nie ciążyły na niej jeszcze funkcje ikonograficzne i estetyczne, prowadzace wprost, jak twierdzi Švankmajer, w niebezpieczne rewiry ideologii totalitarnych albo przeobrażające ją $\mathrm{w}$ towar na rynku sztuki. Sztuka za pośrednictwem surrealizmu może powrócić do "godności magicznej” - twierdzi artysta (Jiný vzduch, Švankmajer 39). Nie traktuje więc surrealizmu jako doktryny jedynie estetycznej, lecz wiodącej także do zmiany świata i życia. Jest przekonany, iż surrealizm nie jest sztuką, a raczej podróżą w głąb duszy, a więc samopoznania, podobnie jak alchemia czy psychoanaliza. „W odróżnieniu od nich, nie jest to droga indywidualna, a raczej podróż kolektywna" (Švankmajer 2001: 129). Ivo Purš, opisując sytuację, w jakiej w latach siedemdziesiątych znalazła się "Grupa Surrealistyczne w Czechosłowacji”, po- 
twierdza, iż skupiono się wtedy przede wszystkim na pracy zbiorowej, na interdyscyplinarnych eksperymentach poszukujących nowych możliwości komunikacji międzyludzkiej przy pomocy obiektów artystycznych (Purš 229-230).

Sarkazm, cynizm, wyobraźnia i mistyfikacja, jak twierdzi Švankmajer, stanowić mogą skuteczną metodę walki ze zdeprawowaną cywilizacją. Punktem wyjścia działań artystycznych pozostaje wyobraźnia. To z niej wypływają zainteresowania eksperymentami taktylnymi. Szereg prac taktylnych i teoretycznych dotyczących tego zagadnienia powstało w okresie, kiedy Švankmajerowi zakazano realizowania filmów animowanych. František Dryje, czołowy współczesny surrealista czeski, interpretuje koncepcję artystyczną Švankmajera jako antycywilizacyjne, radykalne poszukiwanie ukrytego, wymykającego się racjonalizacji sensu. Wnioskuje, że „wielowarstwowa i wielostronna działalność Jana Śvankmajera może stanowić próbę częściowej demonstracji tej zasady" (Dryje 231).

Brytyjski badacz czeskiego kina Jonathan Owen przypomina o podpisanym w 1968 roku wspólnym manifeście artystów francuskich i czechosłowackich Platforma praska, w którym surrealizm potraktowany został jako reakcja na działania systemów represyjnych (kapitalistycznego i komunistycznego). Sztuka surrealistyczna służyć mogła objawieniu rzeczywistości subiektywnej, wyzwolonej spod utylitarności i sztampowości myślenia schematycznego. W manifeście czytamy między innymi:

Rola surrealizmu polega na oderwaniu języka od systemu represyjnego i uczynienie zeń instrumentu pragnienia. Tak więc to, co nazywa się „sztuką" surrealistyczną, nie ma żadnego innego celu niż wyzwolenie słów, lub ogólniej mówiąc znaków, z kodów użyteczności i rozrywki, aby odzyskać je jako nośniki objawienia rzeczywistości subiektywnej (Owen 239).

Owen słusznie zauważył, że generalne przesłanie manifestu współgra ze sposobem pojmowania działań artystycznych przez Švankmajera, choć nie był on sygnatariuszem tego tekstu, bowiem:

„Polemika" Švankmajera z własnym społeczeństwem dotyczy w głównej mierze kwestii komunikacji i ekspresji (artystycznej i wszelkiej innej) języka w najszerszym sensie, a nawet innych sposobów odnoszenia się do świata i interpretowania go. Polemika ta uobecnia się niekiedy na poziomie tematycznym, na ogół jednak zostaje ucieleśniona w artykulacji formalnej jego filmów. Trudno się dziwić, że jest to polemika silnie określona przez idee psychoanalityczne. Eksploracja zależności pomiędzy konkretnymi formami ekspresji a "ja wewnętrznym” (określanym jako fantazja, pożądanie lub popędy libido) jest od dawna głównym aspektem surrealizmu, a także szerzej pojętej awangardy. Švankmajer jest zainteresowany "urabianiem" nowego rodzaju artykulacji filmowej, która jest w stanie „wypowiedzieć” zawartość i uchwycić ruch myślenia podświadomego (Owen 238-239). 
Działania animacyjne, które wciąż podejmuje czeski artysta, zwracają uwagę swoistym podejściem do natury ożywianych przedmiotów. Owen zwraca uwagę, iż operacje dokonywane na nich "owo nieustanne rozbijanie i niszczenie przedmiotów, które występuje w całej jego twórczości, pozwala nam zobaczyć wyraźnie, z czego te przedmioty są zrobione, kruchość lub wytrzymałość ich tworzywa" (Owen 240). Dostrzega też rodzime źródło tych praktyk. Grupa Surrealistyczna założona przez Karela Teigego, a potem kierowana przez Vratislava Effenberga, prowadziła eksperymenty dotykowe na wzór praktyk alchemicznych. Dla Švankmajera mieszanie, stapianie, prucie, rozrywanie i wszelkie inne destrukcje materiałów i obiektów nie są gestem niszczenia, prowadzą do transmutacji sensu, wydobycia ukrytego znaczenia, autentycznej ekspresji skrywanej w podświadomości. Uwalnia ją z nich wyobraźnię - tworzywo wszelkich działań artystycznych.

Peter Hymes, analizujący jeden z filmów czeskiego artysty pod tytułem Možnosti dialogu (Wymiary dialogu, 1982), pozostaje sceptyczny wobec możliwości urzeczywistnienia tych założeń, dostrzegając połowiczny efekt twórczych zamierzeń:

Chociaż poglądu Švankmajera, że przedmioty mogą przekazywać emocjonalne „informacje", nie da się odzwierciedlić w filmie, wrażliwość autora na faktury i materiały umożliwiła właściwą selekcję i „montaż totalny”, który uwidacznia wymiar dotykowy poszczególnych materiałów: drucianej szczotki i plastiku podczas ostrzenia chleba, gdy zostaje on opleciony sznurówkami, grafitu ołówka, który przebija się przez pastę do zębów (Hymes 322-323).

Nie ulega wątpliwości, że w przeniesieniu reguł sztuki haptycznej (haptic art) do filmu niemożliwe jest spełnienie podstawowego założenia, czyli kontaktu, swoistej komunikacji z dziełem sztuki przy pomocy dotyku, pobudzającego wszystkie zmysły. Wydaje się jednak, że Śvankmajera interesuje, co wielokrotnie powtarzał, nie tyle bezpośredni kontakt z materią, z której powstaje obiekt artystyczny (choć ogromne znaczenie przywiązuje do niego w czasie procesu twórczego), ile pamięć dotyku, wszystkich emocji, skojarzeń, wrażeń z nim związanych.

Znaczenie zmysłu dotyku dla procedur twórczych $w$ animacji nie jest zjawiskiem niedocenionym przez innych twórców animacji. Rosyjski animator Jurij Norstein podkreśla, iż kontakt artysty z materią poddawaną przekształceniom jest warunkiem niezbędnym procesu twórczego. Wyznaje: „ja wszystkiego muszę dotknąć własnymi rękami", a stanowisko pracy, przy którym wykonuje swoje zdjęcia do filmu - „musi być dostosowane do moich rąk, musi nastąpić zjednoczenie moich rąk z moim warsztatem pracy, który nie jest dla mnie martwą aparaturą, lecz czymś żywym" (Nortsein 76-77).

Na drodze twórczego rozwoju Švankmajera idee i założenia surrealistyczne pojawiły się jako wynik poszukiwania indywidualnej, najwłaściwszej formy eks- 
presji ${ }^{4}$ Znamienne, że dla Švankmajera językiem, który umożliwia dotarcie do nieujawnionych sensów jest swoiście rozumiany język poetycki zbudowany na analogii, którą posługuje się dziecko w procesie poznania: „Wiedza ta nie ginie bynajmniej z racjonalizacją lat późniejszych: wyparta $\mathrm{w}$ głąb podświadomości, oddziałuje nadal, przekształcona w symbol lub obraz poetycki" (Švankmajer 1997/1998: 236). Poezję postrzega jako swoisty system artystyczny zakorzeniony w praktykach magicznych, służących obronie przed realnością prowadzącą do myślowego wyjałowienia i represji, zatem twierdzi:

Pojęcie poezji stapia się dla mnie z pojęciem wyobraźni, zaś siła wyobraźni stanowi według mnie kryterium wartości poezji, wyrażanej dowolnymi środkami: za pomocą pióra, pędzla, kamery lub dotyku. Jest to pewnego rodzaju kataklizm, jaki co jakiś czas, w chwilach natchnienia, jesteśmy zdolni zsyłać na rzeczywistość, aby - dzięki namułom lub opadom popiołu - odzyskała dla nas żyzność lub, mówiąc inaczej, była znów możliwa do zniesienia (Švankmajer 1997/1998: 239).

Za jeden z kluczowych fenomenów poezji prascy surrealiści z połowy lat siedemdziesiątych uznali analogię. Jak podkreśla Ivo Purš, zdefiniować ją można jako:

podstawową siłę napędową poezji, ale także ogólniej, jako niezbędny impuls psychiczny, pozwalający świadomości człowieka przekroczyć wąskie granice racjonalności i skierować się ku bardziej uniwersalnym formom myślenia (Purš 30).

\section{Švankmajerowska wyobraźnia dotykowa}

Film z 1989 roku Tma-světlo-tma/ Światto-ciemność-światto, to opowieść o powstaniu człowieka/humanoida. Z ciemności, z glinianej materii tworzone są kolejne części ciała $\mathrm{w}$ narzuconym przez artystę swoistym porządku stworzenia, który odzwierciedla jego własną hierarchię dyspozycji istotnych i definiujących człowieka. "Na początku były”... dłonie uosabiające zmysł dotyku, najbardziej pierwotnego, najgłębszego zmysłu, za pomocą którego dotrzeć możemy do zakamuflowanej pamięci naszego jestestwa, potem oczy (wzrok), uszy (słuch), nos (węch), język i zęby (smak). Przychodzi czas na mózg i płeć, dalsze części ciała i organy. W tej opowieści dostrzec można wykładnię Švankmajerowskiej ontologii człowieka, w której artysta przypisuje zmysłom pierwotne i fundamentalne znaczenie.

${ }_{4}^{4}$ Tymczasem poetyzm propagowany w latach trzydziestych przez Karela Teigego i Vítěslava Nezvala znacząco różnił się od surrealizmu za sprawą swego „iluzjonistycznego zachwytu” dla wizji nowego świata, podczas gdy surrealizm nie podziela ich optymizmu cywilizacyjnego. Oprócz wielu różnic, łączył ich jednak nacisk kładziony na rolę wyobraźni w poezji. 
Poszukując możliwości przeniesienia tego doświadczenia $\mathrm{w}$ sferę sztuki, szczególną wagę przywiązuje do środków wyrazowych filmu, w tym makrodetalu uchwyconego w ruchu. Pozwala on ukazać wszelkie jego aspekty. Poprzez analizę struktury obiektów umożliwia dojście do zapośredniczonego doświadczenia taktylnego, wymuszającego pracę pamięci (Švankmajer 1997). Za pomocą zmysłu dotyku można docierać do podświadomych, niepoznanych lub zapomnianych przeżyć, emocji, wrażeń, wspomnień, można zaktywizować wyobraźnię w niedostępny dla pozostałych zmysłów sposób. W datowanym na 1978 rok tekście zatytułowanym Taktilní imaginace (Wyobraźnia taktylna) Švankmajer przedstawia koncepcję taktylności wywiedzionej z relacji synestezyjnych, traktowanych jako relikt starszego stadium filogenezy. W rozważaniach nad rolą i współpracą zmysłów, najczęściej wskazuje się na powiązania między wzrokiem i słuchem. Tymczasem, zdaniem Śvankmajera, to dotyk jest najpierwotniejszym zmysłem, którym zaczynamy odbierać świat jeszcze przed wzrokiem, stąd jego doświadczenie jest fundamentalne. O nieoczywistej relacji między barwą a dotykiem napomykał już Karel Teige w Drugim manifeście poetyzmu (1924). Zdaniem Švankmajera skomplikowane zjawisko synestezji między wzrokiem a dotykiem tworzy jedność percepcyjną. Dotyk wszedł w zależności ze wzrokiem jako „fałszywa synestezja”, na innej zasadzie niż relacja analogii jaka wiąże wzrok ze słuchem. Nie podziela przekonania o dominującej roli wzroku jako zmysłu, który podporządkowuje sobie pozostałe i akceptacji dominującego statusu dotyku jedynie w sferze życia erotycznego. Zwraca uwagę, iż uznając jego „upośledzoną” pozycję jednocześnie można charakteryzować barwy przy pomocy określeń ciepłe/zimne. Podobnie dzieje się w odniesieniu do materii. Na przykład drzewo kojarzy się z materiałem ciepłym, a szkło czy metal z zimnem. Idąc tym tropem, twierdzi Švankmajer, przedmioty $w$ obiektach taktylnych wytworzone $\mathrm{z}$ "materiałów ciepłych”, powinny wywołać skojarzenie z takimi kolorami, a "zimne" ewokowałyby relacje z barwami „zimnymi”. Właśnie taką klasyfikację porównawczą Švankmajer nazywa nietypowymi "fałszywymi analogiami”. Zadaniem sztuki taktylnej jest przywrócenie dotykowi statusu samodzielnego zmysłu i zdetronizowanie wzroku jako dominatora $\mathrm{w}$ postrzeganiu zmysłowym. Dotykanie ukrytego przed wzrokiem przedmiotu aktywizuje „wewnętrzne postrzeganie”, wizualizując fantom obiektu za sprawą poruszonej wyobraźni - głosi praski artysta (Švankmajer 1990).

Od połowy lat siedemdziesiątych zajmuję się eksperymentami taktylnymi. Z początku wyglądało to na przypadkową grę. Wytworzyłem obiekt dla kolektywnego taktylnego eksperymentowania $\mathrm{w}$ ramach problematyki interpretacji, którym właśnie zajmowaliśmy się w Grupie Surrealistycznej. Ale wyniki były na tyle inspirujące, że wypełniłem tymi eksperymentami siedem lat w czasie, kiedy nie mogłem realizować własnych filmów. Kiedy na początku lat osiemdziesiątych otworzyła się możliwość ponownej pracy nad animowanym filmem, oczywiście stale powracała myśl, jak wykorzystać swoje taktylne „doświadczenia”. Na pierwszy rzut oka wydaje się to paradoksalne - przecież 
film jest w pełnym tego słowa znaczeniu, zjawiskiem audiowizualnym ${ }^{5}$ (Švankmajer 2001: 137-138).

Eksperymenty taktylne czeski artysta rozpoczął w 1974 roku. Wtedy też stworzył pierwszy taki obiekt nazwany „Restaurator". Był on dotykową interpretacją przypadkowo wyciętego z czasopisma obrazka, który przedstawiał restauratora przy pracy. Zmieszany z dziewięcioma obrazkami musi zostać odnaleziony i zinterpretowany przez grupę uczestniczących w eksperymencie. Badania nad możliwością uaktywnienia wyobraźni przy pomocy zmysłu dotyku Švankmajer kontynuował w twórczości indywidualnej, tworząc taktylną poezję, rzeźbę i kolaże.

W latach osiemdziesiątych Artysta prowadził dziennik taktylny, w którym zapisywał związane $\mathrm{z}$ życiem codziennym własne doświadczenia dotykowe, ale przede wszystkim starał się zapisywać "taktylne sny", w których doznania tego typu otwierały możliwości snucia onirycznych skojarzeń.

W notatce z 3 marca 1985 roku zapisał nie tylko wrażenia senne, ale także komentował istotę doświadczenia taktylnego. Zdaniem Švankmajera, szczególne znaczenie ma bezpośredniość kontaktu między odbiorcą a przedmiotem. Komunikacja $\mathrm{z}$ dziełem odbywa się jedynie na poziomie subiektywnego przeżycia. Tymczasem, zdaniem artysty, obiekt taktylny przy każdym kontakcie zostaje wzbogacony o emocje kolejnego odbiorcy akumulując je w sobie. W ten sposób emocjonalna zawartość obiektu taktylnego nieustannie się zmienia. Ta permanentna metamorfoza jest specyficzną cechą sztuki taktylnej (Švankmajer 1992: 54). Fundamentalny dla niej, według omawianego Artysty, proces kumulacji wrażeń emotywnych, tłumaczy, dlaczego artysta poddaje procedurom animacyjnym przedmioty stare, zniszczone, intensywnie używane. Fascynuje go tajemnica przedmiotów z nagromadzoną historią licznych użytkowników, którzy pozostawili $\mathrm{w}$ nich ślady swoich emocji. Dodatkowo zauważamy $\mathrm{w}$ jego działaniach twórczych predylekcję do animowania materii i substancji budzących odrazę czy niechęć, takich jak surowe mięso (Zamilované maso/Zakochane mięso, 1980), błoto (Zaník domu Usherů/Upadek domu Usherów, 1980), ludzkie trzewia czy mózg (Konec stalinizmu $v$ Čechach/Koniec stalinizmu w Czechach, 1990). Zabiegi te zbliżają jego praktykę artystyczną do „sztuki abjektu” (abject art), nastawionej na intensywne, agresywne działanie na zmysły odbiorców.

Švankmajer stworzył także małą antologię sztuki taktylnej, w której zgromadził wiele materiałów i dzieł na temat dotyku i wyobraźni. Zainteresował się stanowiskami w materii sztuki taktylnej takich twórców jak: Filippo Tommaso Marinetti, Guillaume Apollinaire, Marcel Duchamp, Salvador Dali, Max Ernst czy Frederick John Kiesler (Švankmajer 2008).

\footnotetext{
5 Tłumaczenie własne.
} 
W 1983 roku artysta zebrał swoje doświadczenia i przemyślenia dotyczące taktylizmu w pracy Hmat a imaginace (Dotyk i wyobraźnia), którą wydał w formie artystycznego samizdatu. Pięć egzemplarzy wyróżnił taktylną oprawą. Maszynopis oprawiony został w twardą, kartonową okładkę obciągniętą szarym płótnem, na której widnieje odbity odcisk dłoni, zachęcając czytelnika do przyłożenia swojej. Grzbiet książki sporządzono z „rozczesanych” frędzelków, które utworzyły białą, miękką, puszystą "grzywę" książki, zachęcającą do pogłaskania...

Teoretycy sztuki szukali odpowiedzi na pytanie, dlaczego Švankmajer, twórca sztuk wizualnych, stał się wyznawcą taktylizmu. František Dryje sugeruje psychoanalityczny podtekst tego gestu. Motywuje to faktem, iż w sztuce wyrastającej z poetyki onirycznej, uruchamiany jest „wzrok wewnętrzny”. Sytuację objaśnia następująco:

Dotyk jest, według autora, niesłusznie lekceważonym zmysłem, który oczekuje dopiero triumfalnej rehabilitacji. Pierwszym, który oddaje się orgiom dotyku, pojętego jako kreator działań, jest sam twórca, ogarnięty obsesją aktywności manualnej, spragniony dotyku materii nie zapośredniczonej przez słowo lub pędzel, lecz kształtowanej wprost dłońmi przy produkcji kukiełek, strukturalnych asamblaży, animowanych sekwencji filmowych, naczyń ceramicznych czy choćby lepkich od kleju kolaży, by nie wspomnieć o umyślnym, świadomym sporządzaniu obiektów taktylnych oraz taktylnym eksperymentatorstwie, do którego Švankmajer wciąga z maniacką energią partnerów, czynić z nich ślepe narzędzia swej taktylnej woli i opętania. Dotyk, zmysł cielesny, który niewątpliwie koordynuje współdziałanie wszystkich zmysłów w procesie seksualnego dojrzewania człowieka, jest dla Švankmajera nosicielem komunikatów i przesłań z interna podświadomości, z głębin ludzkiej duszy, a więc stanowi czynnik znaczeniotwórczy. Spostrzeżenia dotykowe nie tylko stymulują i prowokują skojarzenia wizualne; sama pamięć dotykowa jako przesłanka sztuki taktylnej jest $\mathrm{w}$ tym sensie nieomylną organizatorką rzekomego chaosu procesów wyobraźni i możliwe, iż tu właśnie, $\mathrm{w}$ nieredukowalnym magnetyzmie zmysłowego przyciągania i odpychania, nie mającym nic wspólnego z tradycyjnym pojmowaniem piękna, odnajdujemy jeden z korzeni kreacyjności jako metody uzewnętrzniania tego, czym jesteśmy (Dryje 234).

W 2003 roku Švankmajer zreasumował swoje trzydziestoletnie doświadczenia ze sztuką taktylną. W tekście podsumowującym eksperymenty zwrócił uwagę, iż istnieje coś takiego jak pamięć taktylna przywołująca wspomnienia z dzieciństwa zbudowane na wspomnieniu dotyku. Na przykład relacja Vratislava Effenberga dotycząca dziecięcych przeżyć z próbą pogłaskania świątecznego karpia, czy przywoływane przykre wspomnienia Emili Medkovéj ${ }^{6}$. Švankmajera interesował

${ }^{6}$ E. Medková, powracając do lat dziecinnych, wspomina jedno ze spotkań z biedną dziewczynką mieszkającą w jej domu. Dziewczynka zachęciła Emilię, by włożyła rękę do jej kieszeni, w której, jak zapewniała czeka na nią smakowita niespodzianka. Medková, uczyniwszy to, poczuła nieprzyjemną lepką masę i z obrzydzeniem wyciągnęła rękę. Okazało się, że był to gotowany groch. 
także synestezyjny potencjał dotyku, dlatego analizował relacje między wzrokiem a dotykiem. Stały się one w pierwszym rzędzie przedmiotem jego licznych eksperymentów taktylnych, ale uznać można także, iż jego twórczość filmowa nakierowana była na podobne doświadczenie. Związki dotyku i powonienia oraz dotyku i smaku nie zostały jeszcze dostatecznie przebadane. Podobnie rzecz ma się z relacją między dotykiem a słuchem. Zdaniem czeskiego artysty, w efekcie dysponujemy ubogim słownikiem taktylnym, który ogranicza się jedynie do przeciwstawnych par pojęciowych: mokry-suchy; ciężki-lekki, szorstki-gładki, stały-sypki, ciepły-chłodny. Stąd nieuniknione przy opisie bardziej skomplikowanych stanów doświadczeń związanych z cielesnością jest użycie metafor, analogii, czyli środków poetyckich. Ten niedostatek leksykalny z drugiej strony sprzyja tworzeniu poezji taktylnej (Švankmajer 2003).

Swoje eksperymenty i teoretyczne roztrząsania Švankmajer równolegle „sprawdzał" w praktyce filmu animowanego. Studiując prozę Edgara Allana Poe, uświadomił sobie, jak wielkie znaczenie w jego świecie literackim odgrywa dotyk. Zánik domu Usheru autorstwa Švankmajera można uznać za taktylną adaptację opowiadania E. A. Poe. Jak twierdzi sam Śvankmajer, pierwszy raz zastosował pośrednictwo wyobraźni taktylnej w sekwencji przedstawiającej animację trzęsawiska, stanowiącej analogię do poetyckiej wizji rodzącego się szaleństwa bohatera opowiadania Poe. Komentatorzy praskiego czasopisma „Film a doba” podkreślili, że filmowy Usher wyczuwa swoją tożsamość rękami i bosymi stopami. Subiektywna kamera obserwuje ciało bohatera tylko z jego perspektywy, co za pomocą sugestywnej iluzji pozwala widzowi wspólnie z nim przeżywać cielesne doświadczenie (-ná- 257-258).

Podobny zabieg Švankmajer zastosował w sekwencji filmu Možností dialogu Dialog vášnivý, gdzie przemiany kochanków dokonywały się za sprawą destrukcyjnego dotyku, a gest ten stał się podstawą taktylnej metamorfozy. Podjął także kwestię możliwości komunikacyjnych, zwracając uwagę na pierwsze medium, jakim są dłonie poszukujące, sprawdzające i poznające materię. Za sprawą dotyku, taktylnych manipulacji na materiale (glinie, kuchennych przyborach, przedmiotach codziennego użytku) obiekty ulegają przemieszczeniu, transmutacji, metamorfozie, które podważają ich ustalony status, zacierają granicę między realnością a iluzją, rzeczywistością i snem.

W filmie Kyvadlo, jáma a naděje/Wahadto, studnia i nadzieja, 1983 taktylizm jest centralną metodą przekształcania tekstu literackiego na obraz. Tutaj tortura, według słów artysty, staje się granicznym przejawem taktylizmu (Švankmajer 2003: 27-29). Z kolei Něco z Alenki/Coś z Alicji, 1988 jest próbą nawiązania dialogu ze swoim własnym dzieciństwem, jako drugim ,ja” przy pomocy sensorycznych doznań (Švankmajer 1989).

Jeśli prześledzimy twórczość animacyjną Švankmajera, odkryjemy, że dominującą emocją w jego filmach jest strach. Sam Artysta wyjaśnia, że nie chodzi o epatowanie niebezpiecznymi sytuacjami, nie interesuje go konwencjonalne gatunko- 
wo (horror) wywoływanie lęku u odbiorcy. Motyw irracjonalnego strachu przed nieznanym ma swoje korzenie $\mathrm{w}$ dziecięcym doświadczeniu poznawania świata. To właśnie ta radykalna emocja rozwija w nas potrzebę wyobraźni, podkreśla Švankmajer (Švankmajer 1997).

Swoje doświadczenia teoretyczne oraz prace eksperymentalne dotyczące taktylizmu Jan Švankmajer kumuluje w filmie Spiklenci slasti/Spiskowcy rozkoszy, 1996. Przeprowadza analizę faktur różnych przedmiotów: ostrych części składowych aparatu radiowego, miękkich i ciepłych ptasich piór, szorstkości i miękkości tkanin i futer, chłodu i neutralności faktury papieru, wrażeń lepkości kleju, dyskomfortu z kontaktu z gumowymi rękawiczkami, czy budzące ambiwalentne reakcje zmysłowe dotykanie żywego karpia, niedefiniowalnej przyjemności zgniatania miąższu chlebowego, itd. Przedmioty, z których bohaterowie konstruują obiekty służące ich tajnym rozkoszom, poddawane są unaocznionym praktykom taktylnym: krojeniu, cięciu, wierceniu, polerowaniu, lizaniu, całowaniu, gnieceniu, malowaniu, darciu, szyciu, pruciu, gładzeniu, wiązaniu, wyrywaniu, lutowaniu, przybijaniu. Narzędziem tych czynności są dłonie. Funkcję tą pełnią także inne części ciała, na przykład twarz i język "potrafiący docenić” taktylne jakości obiektów. Poprzez obserwacje wszelkich manipulacji na przedmiotach, a także zróżnicowanych materiach: krwi, lakierze do paznokci, wosku, masie papierowej, za pośrednictwem wzroku obserwator wprowadzany jest w świat doznań dotykowych. Odczuwa jakość obiektów zardzewiałych, podgniłych, mokrych, zakurzonych, lepkich, zimnych, ciepłych, itd. Intensywne uruchomienie zmysłu dotyku zapośredniczonego przez wzrok służy aktywizacji wyobraźni, która przywołuje nieuświadomione, ukryte doznania i pragnienia.

Warto jednak podkreślić, że dowartościowując zmysł dotyku jako głównego „wyzwalacza” nieznanych pokładów naszej wyobraźni Švankmajer wskazuje na współdziałanie wszystkich zmysłów w procesie doświadczania emocjonalnego. Tym samym daje pierwszeństwo intuicyjnemu sposobowi poznania nad racjonalnym. Wrażenia taktylne silnie powiązane są ze zmysłem smaku, który niejako automatycznie uruchamia operacje dotykowe na obiektach i materiach. Niewątpliwie ogromną rolę poza wizualnością pełnią w filmach Švankmajera wrażenia słuchowe. Materia obiektów poddanych oglądowi zawsze dodefiniowana jest przez dźwięki: szelest, skrzypienie, stukot, itd., jako skutek różnych form kontaktu cielesnego. W filmie Jan Sebastian Bach - Fantasia g-moll, 1965, wrażenia taktylne związane z wizualnym opisem starego domu wspomagane są przez muzykę barokowego mistrza. Podobnie jak we wszystkich filmach Švankmajera muzyka nie służy prostej ilustracyjności, lecz wspiera rytmizację przemijających obrazów ${ }^{7}$. $\mathrm{W}$ wielkich zbliżeniach skupia uwage na fakturze zniszczonych ścian, odpadającego tynku, załamań, szpar i szczegółach opustoszałych wnętrz.

\footnotetext{
7 Podobną funkcję pełni muzyka Zdeňka Liški w filmie Rakvikčárna/Trumniarnia, 1966.
} 
Realizując koncepcję taktylizmu, Jan Švankmajer w swojej twórczości filmowej zmierza do reorganizacji utylitarnego porządku świata. Burzy hierarchię relacji między światem ożywionym i nieożywionym. Staje się głosem sprzeciwu wobec tendencji dehumanizacyjnych we współczesnym świecie. Praktyki artystyczne nie są wymierzone przeciwko człowiekowi. Nie prowadzą do reifikacji ludzi, ale są próbą człowieczeństwa w najpełniejszym wymiarze. Głos Švankmajera w sprawie docenienia wyobraźni jako wartości humanistycznej wpisuje się w szerszą refleksję nad kondycją współczesnego człowieka. Jedno z przykazań Švankmajerowskiego Dekalogu potraktować można, jako motto całej jego twórczości:

Wyobraźnia obala porządek rzeczy, ponieważ przeciwstawia możliwe rzeczywistemu. Dlatego używaj tej najbardziej szalonej formy wyobraźni. Wyobraźnia to największy dar, jaki otrzymała ludzkość. Wyobraźnia, a nie praca uczłowieczyła ludzi. Wyobraźnia, wyobraźnia, wyobraźnia... (Švankmajer 2001: 11).

\section{BIBLIOGRAFIA}

„Dochodzenie do Gogola. Z Jurijem Norsteinem rozmawia Janusz Gazda”. Kwartalnik Filmowy 19-20 (1997/1998). S. 74-97.

Dryje, František. „Inny wzrok”. Przeł. Jan Gondowicz. Kwartalnik Filmowy 19-20 (1997/1998). S. 231-235.

Engelking, Leszek. Surrealizm underground postmodernizm. Szkice o literaturze czeskiej. Łódź: Wydawnictwo Uniwersytetu Łódzkiego, 2001.

Giżycki, Marcin. „Magia Jana Švankmajera”. Kwartalnik Filmowy 19-20 (1997/1998). S. 228-230.

Hymes, Peter. Czechostowacka Nowa Fala. Przeł. Irena Hansz. Gdańsk: Słowo/Obraz Terytoria, 2009.

Jiný vduch. Skupina česko-slovenských surrealistů 1990-2011. Výstava s mezinárodní účastí. Staroměstská radnice v Praze. 10.02.- 4.04.2012. Praha: Art. Movement o.s. Analogon, 2012.

Kino epoki nowofalowej. Red. Lubelski, Tadeusz, Sowińska, Iwona, Syska, Rafał. Kraków: Universitas, 2015.

Majmurek, Jakub. "Spiskowcy rozkoszy”. Krytyka polityczna. Dziennik opinii. Web. 4.12.2015. <http://www.krytykapolityczna.pl/artykuly/film/20121218/spiskowcy-rozkoszy>

„Nie zamierzam popełnić samobójstwa. Z Piotrem Dumałą rozmawia Małgorzata Pawłowska-Tomaszek". Kwartalnik Filmowy 19-20 (1997/1998). S. 127-129.

-ná-; L.Š. „Nové filmy Jana Švankmajera”. Film a doba, 1984, s. 593-599. W: Animace a doba. Sborník textů $z$ časopisu Film a doba 1955-2000. Wybral, uspořádal a doplnil Stanislav Ulver. Praha: Sdružení přátel odborného filmového tisku, 2000. S. 256-258.

Owen, Jonathan L. „Współczesny surrealizm czeski i odnowa języka. Wczesne filmy Jana Švankmajera". Przeł. Michał Szczubiałka. Panoptikum. Kino i sztuka*/zaangażowanie społeczne. Audiowizualia Film/Media/Sztuka 7 (2008). S. 237-258.

Purš, Ivo. „Osudy povalečného československého surrealizmu”. Inicialy 5-6 (1990). Vol. 1. Za: Engelking, Leszek. Surrealizm, underground, postmodernizm. Szkice o literaturze czeskiej. Łódź: Wydawnictwo Uniwersytetu Łódzkiego, 2001.

Švankmajer, Jan. "Jak přežit život”. Rozhovor Radan Wagner. Revue Art. Čvrtletník o současném umení. (4) 2008. S. 10-17.

Švankmajer, Jan. "Něco z Alenky”. Film a doba. 1989. S. 492-494. W: Animace a doba. Sborník textů $z$ časopisu „Film a doba" 1955-2000. Wybral, uspořádal a doplnil Stanislav Ulver. Praha: Sdružení přátel odborného filmového tisku, 2000. S. 301-302. 
Švankmajer Jan. „O úzkosti, spiklencích a slastech filmu. Rozhovor s Janem Švankmajerem”. Připravil Stanislav Ulver. Film a doba. 1997. S. 13-18. W: Animace a doba. Sborník textů z časopisu "Film a doba" 1955-2000. Wybral, uspořádal a doplnil Stanislav Ulver. Praha: Sdružení přátel odborného filmového tisku, 2000.

Švankmajer, Jan. Síla a imaginace. Režisér o své filmové tvorbě. Praha: Dauphin Mladá Fronta, 2001.

Švankmajer, Jan. "Taktilní imaginace”. Analogon. Surrealismus - Psychoanalysa - Strukturalismus - Antropologie - Příčné vědy. Interpretace jako trưrči činnost. 3 (1990). S. 62-63.

Švankmajer, Jan. „Taktilní balance”. Analogon. Surrealismus - Psychoanalysa - Strukturalismus - Antropologie - Př́̌čné vědy. Senzace smyslü 38/39 (2003). S. 27-29.

Švankmajer, Jan. „Z ankiet i wywiadów”. Przeł. Jan Gondowicz. Kwartalnik Filmowy 19-20 (1997/1998). S. 236-239.

Švankmajer, Jan. "Z taktilního deníku”. Analogon. Surrealismus - Psychoanalysa - Strukturalismus Antropologie - Př́̌́né vědy. Na cesty Her 6 (1992). S. 53-54.

"The (Surrealist) Platform of Prague - The Vessels Always Communicate". Web. 12.12.2015. http://criticallegalthinking.com/2011/01/12/the-surrealist-platform-of-prague-the-vessels-alwayscommunicate/ 